Archiv für Mikrobiologie 34, 93-102 (1959)

From the University of Michigan and Indiana University

\title{
Observations on Chytridiaceous Parasites of Phanerogams IX.
}

\author{
Epibiotic Sporangial Stages of Physoderma Collected in the Field
}

By

\author{
F. K. SPARROW and R. M. JoHNs***
}

With 29 Figures in the text

(Eingegangen am 11. Mai 1959)

Fungi belonging to the chytrid family Physodermataceae in an increasing number of instances are known to produce two very different types of plants, (1) a strongly polycentric, endobiotic thallus which bears numerous "turbinate organs" and resting spores and ramifies through many cells of the host, and, (2) a monocentric, epibiotic "ephemeral sporangium" with a short, bushy rhizoidal system within a single host cell. The latter plant, derived from a zoospore from a germinated resting spore, gives rise to motile swarmers which are discharged inoperculately, its sporangium rests on a broad base, is usually internally proliferous, and nearly always bears on it an unexpanded portion of the spore cyst from which it has arisen. This often gives a somewhat humped or gibbose appearance to the whole structure (Fig.14). In a true species of Physoderma, the ephemeral sporangial stage is completely invisible to the naked eye, in contrast to the endobiotic one which produces streaks, pustules, galls, etc. on the host plants.

In only two instances has the epibiotic stage of a Physoderma (exclusive of Urophtyctis) been found in the field, namely by Covcr (1953) in $P$. maydis and JoHns (1958) in P.dulichii. All other studies of the epibiotic stage have been made on material produced in the laboratory by inoculation of host plants with zoospores from germinated resting spores.

These epibiotic structures have been shown in Physoderma lycopi (SPARRow 1957b) and in Urophlyctis pulposa (Y. LINGAPPA 1958) to function as gametangia, their swarmers fusing to form zygotes which, in the latter fungus, at least, are known to give rise subsequently to the endobiotic phase. It seemed logical to suppose, therefore, in these fungi

\footnotetext{
* Acknowledgement is made to the National Science Foundation for financial support given this project.

** Contribution No. 1100, Botany Department, University of Michigan, contribution from the Biological Station, University of Michigan, and the Botany Department, Indiana University.
} 
which exhibited an heteromorphic alternation of generations that the epibiotic phase would precede the endobiotic one and would be present on the host early in the growing season. Accordingly, collections were made in the second week of May, 1958, of various host plants from swampy sites in the vicinity of the University of Michigan Biological Station at Douglas Lake which were known to harbor Physodermainfected plants later in the season. As was expected, these plants were all completely submerged at that time of year. The water temperature varied from $10-13^{\circ} \mathrm{C}$ at the different sites. Three days of intensive microscopic observations of many plants produced conclusive evidence for the occurrence in this area of epibiotic sporangia on four different phanerogamic hosts. Although sporangia bearing zoospores were seen on only two of these hosts, the highly characteristic morphological features earlier mentioned left little question but that they belonged to a Physoderma.

One site in the vicinity of Ann Arbor known to have $P$. (Urophlyctis) pluriannulatum was also visited in early June, 1958, and infected host material (Sanicula) collected.

Since species concepts in this group are perhaps the most nebulous to be found among the fungi, we will not now attempt to apply a binomial to the organisms collected but will merely designate them according to host plants.

\section{Physoderma on Mentha arvensis}

We have collected the endobiotic phase of this fungus through several growing seasons at the same site. Approximately a foot of water covered the host plants in May. Epibiotic sporangia were found in some abundance. These occurred only on the glandular trichomes of the stem (Fig. 1-8). They are pyriform or somewhat anatropous, transversely placed structures, $40-52 \mu$ long, the narrow end $6-8 \mu$, and the broader, $18-25 \mu$ in diameter. The narrow, beak-like apex, $6-8 \mu$ in diameter, was further characterized by having a thickened wall, and was undoubtedly an unexpanded portion of the wall of the zoospore cyst. The whole structure was attached near the narrower end to a short, bushy, endobiotic system of delicate rhizoids which arose from an inconspicuous apophysis. Although various stages of sporangial maturation were observed (Fig. 1, 2,7) no fully mature ones with zoospores were seen. These probably had been discharged during the period immediately following collection. The zoospores had escaped through a pore $5-7 \mu$ in diameter which terminated the broad end of the sporangium (Fig. 1, 4, 6). Internal proliferation of discharged sporangia was common (Fig.1, 3).

These structures undoubtedly belong to the endobiotic fungus found later in the season at the same site whose resting spores conform to 

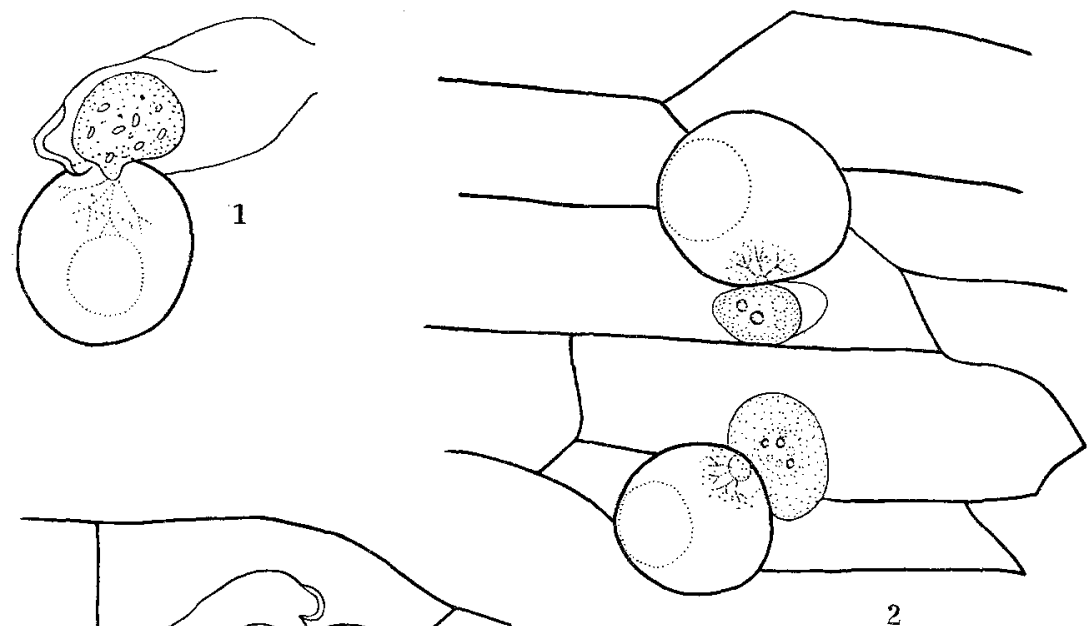

3
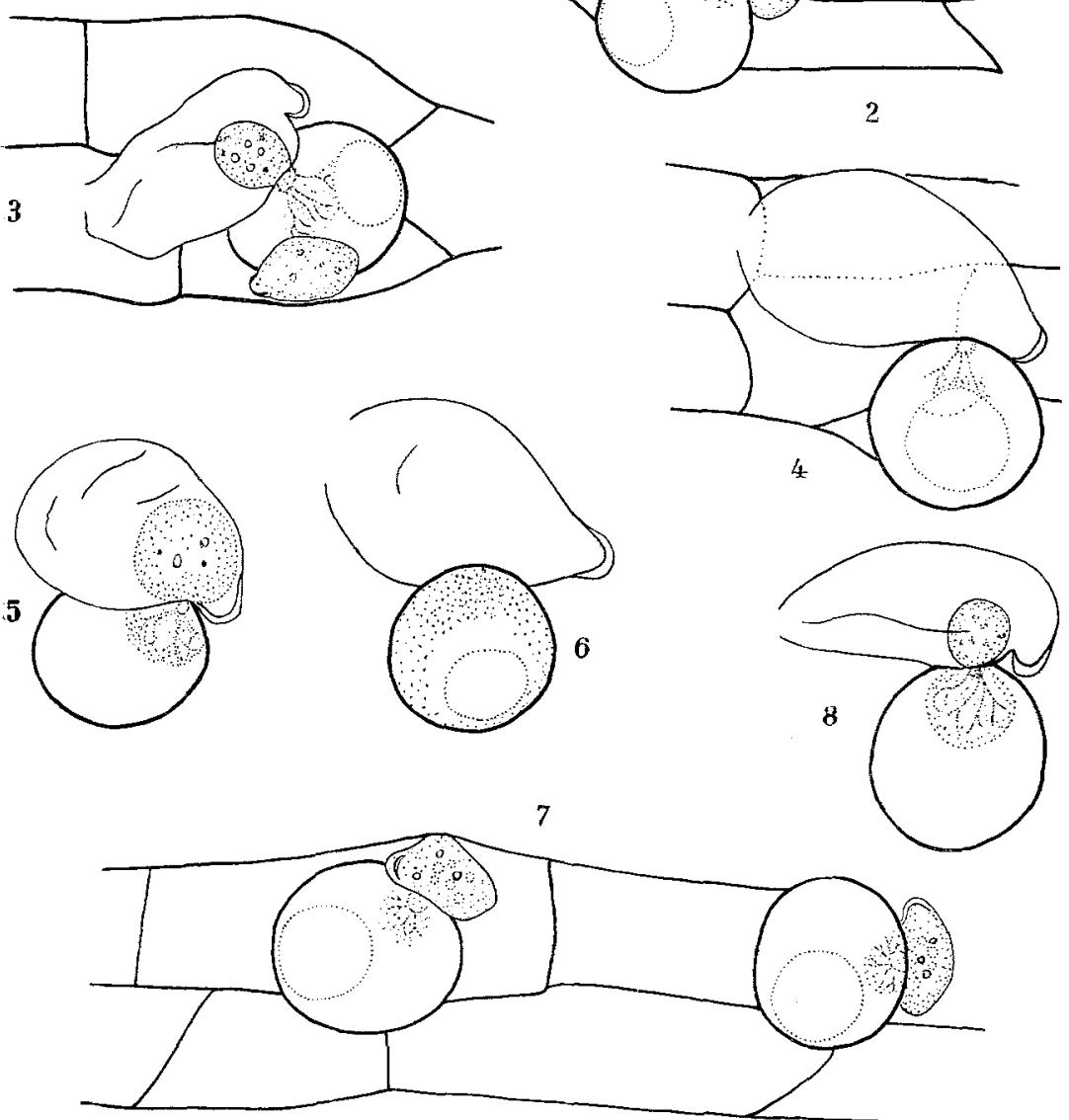

Figs. 1-8. Epibiotic sporangia in various stages of development on the glandnlar trichomes of the sterm of Mentha arvensis. In Figs. 2 and 7 very young stages in development are shown. In Fig. 1 the cyst of the zoospore is shown on the wall of the sporangium; within the latter a new sporangium is ibeing formed by internal proliferation. In all but Fig, 6 the bushy rhizoidal system which arises from a small apophysis may be seen. $x 280$ 
published accounts of Physoderma menthae Schroeter. Although the sporangia of the Mentha parasite resemble those of $P$. lycopi, on another

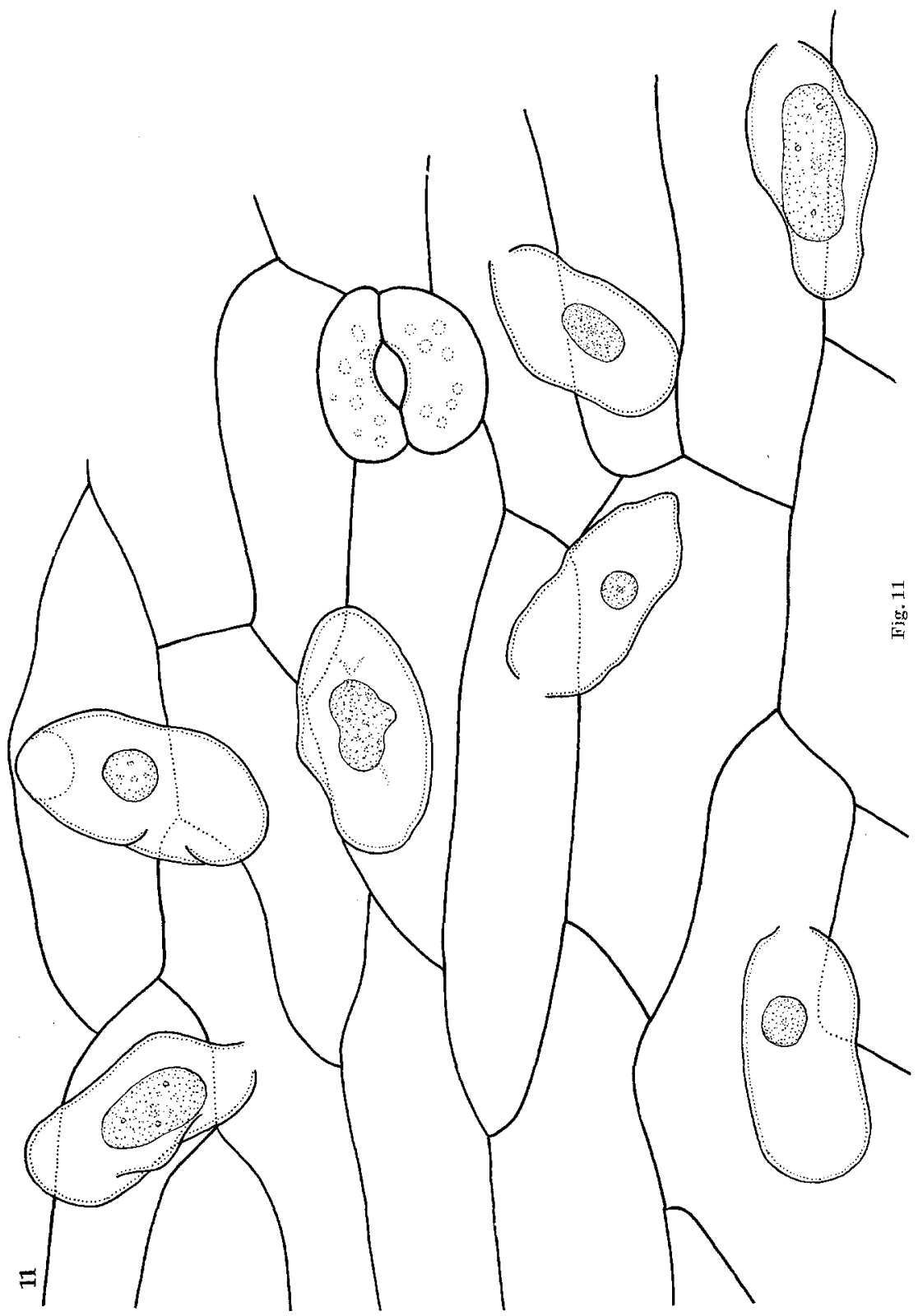

labiate, Lycopus americanus, they differ in certain features, notably size and probably also coloration. In the Mentha fungus they were $40-52 \mu$ 
long by $18-25 \mu$ in greatest diameter, whereas in $P$. lycopi they were $23-26 \times 12-15 \mu$. Furthermore, the thick-walled cyst of the Mentha parasite was uniformly opposite the discharge pore whereas this structure varied in position in $P$. lycopi. It will be recalled that some sporangia (gametangia) of the last-named species formed orange pigment in their protoplasm. There was no evidence for such coloration in the Mentha parasite.

\section{Physoderma on Caltha palustris}

As in the preceding fungus, the endobiotic phase of this organism has been collected through several seasons at the same locality. In early May the site was completely covered. with water.

Epibiotic sporangia were found primarily on the petioles of the leaves, particularly their dilated bases. In the latter region they were frequently associated with deep green streaks of the host tissue. Some evidence of their great abundance

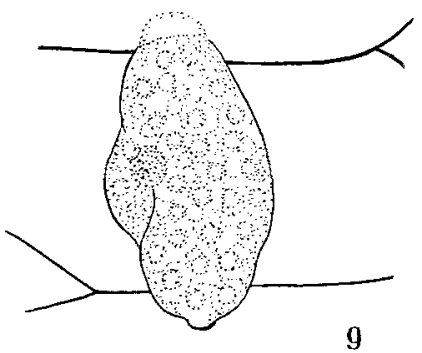

9
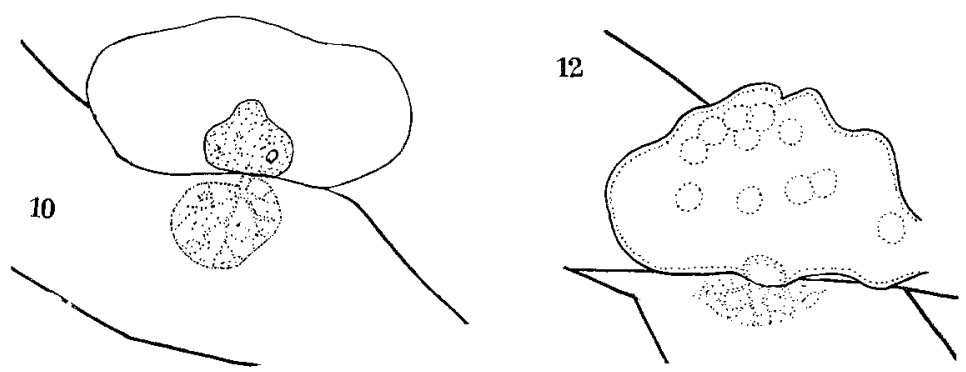

Figs, 9-12. Epibiotic sporangia on Caltha palustris. Fig. 9 is of a mature sporangium with broad discharge papilla at top and cyst of zoospore at opposite end. Figs. 10 and 12 show sporangia in side view; 9 and 11 show them from the top. $\times 280$

on the host may be gained from examining Fig. 11 which is not a composite drawing. Here, in an area approximately $190 \times 150 \mu$ seven sporangia are shown.

Viewed from above (Fig. 9, 11), the transversely affixed sporangia were somewhat irregularly slipper-shaped and sometimes lobed. In side view, however, they appeared somewhat gibbose (Fig. 10, 12). The unexpanded remains of the zoospore cyst was not often visible on these sporangia but seemed to be opposite the $10 \mu$ in diameter discharge pore. The sporangia were remarkably uniform in size, the great majority being $50 \mu$ long by $10-15 \mu$ at the narrow end increasing to $20-28 \mu$ in greatest diameter, and were $25-30 \mu$ high. The bushy rhizoidal system 
within the host cell did not seem, for the most part, to arise from an apophysis.

Some undischarged sporangia survived the trip from field to laboratory and several instances of zoospore liberation were witnessed. Upon the deliquescence of a broad, $10 \mu$ in diameter prominent papilla (Fig.9), the zoospores emerged through a $10 \mu$ in diameter pore, the first ones escaped immersed in the expanding gelatinous papillar material. Later ones escaped by their own flagellar activity. The zoospore was spherical when in motion, $5 \mu$ in diameter, and bore a single, eccentric, refractive, colorless, lense-shaped globule and posterior flagellum. Nearly all empty sporangia showed evidences of internal proliferation (Fig, 10, 11).

\section{Physoderma on Sium suave}

The Physoderma on Sium suave is fairly widespread in Michigan and will be discussed in detail in another paper. Several sites in the vicinity of the Biological Station have, in wet years, an abundance of infected host plants. Unsuccessful attempts were made in the laboratory to produce epibiotic sporangia from zoospores from germinated resting spores. In the field they were recovered in moderate abundance, and as. was expected, on the underwater dissected leaves. They were readily spotted on the surface of the colorless epidermal cells when the latter were viewed "on edge". Unfortunately, because of the dense green coloration of the underlying leaf cells top views of sporangia could not. be obtained.

The sporangia (Fig.13-20) were uniformly gibbose in side view, transversely placed on the host, predominantly $15-28 \mu$ long by $12-18 \mu$. high, and bore apically the characteristic thick-walled, unexpanded portion of the cyst $(4-5 \mu$ in diameter) of the infecting zoospore. The zoospores were discharged (Fig.15) through a pore formed upon the deliquescence of a prominent papilla which terminated one end of the sporangium. They were spherical, $4-5 \mu$ in diameter, bore an eccentric colorless oil globule, a small lateral granule and a conspicuous nuclear cap. There was a single posterior flagellum. Approximately twenty zoospores were produced in primary sporangia. Secondary sporangia. were formed by a process of internal proliferation. Within the host cell there was a delicate, bushy rhizoidal system. Our observations were inconclusive as to whether or not this always arose from an apophysis. As. has been noted in sporangia of other species, the rudiment of the secondary sporangium is often well along in its development by the time discharge of the primary sporangium occurs (Fig.15).

In two instances structures were observed within epidermal cells which we interpret as very young primary turbinate cells. These were pyriform, $15-20 \mu$ long by $12-18 \mu$ wide and were attached to an epibiotic: 

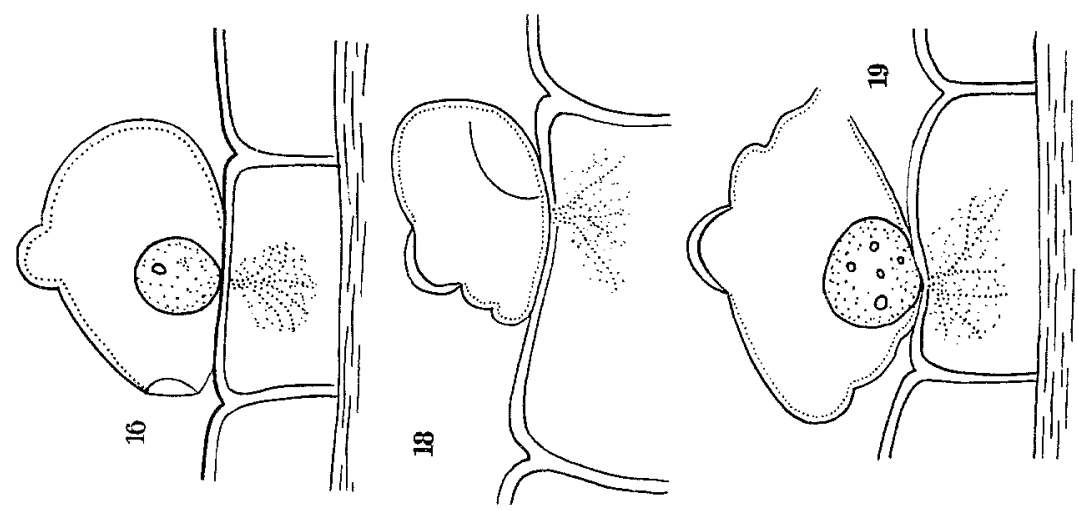

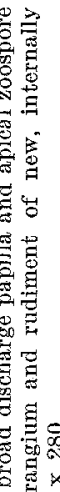
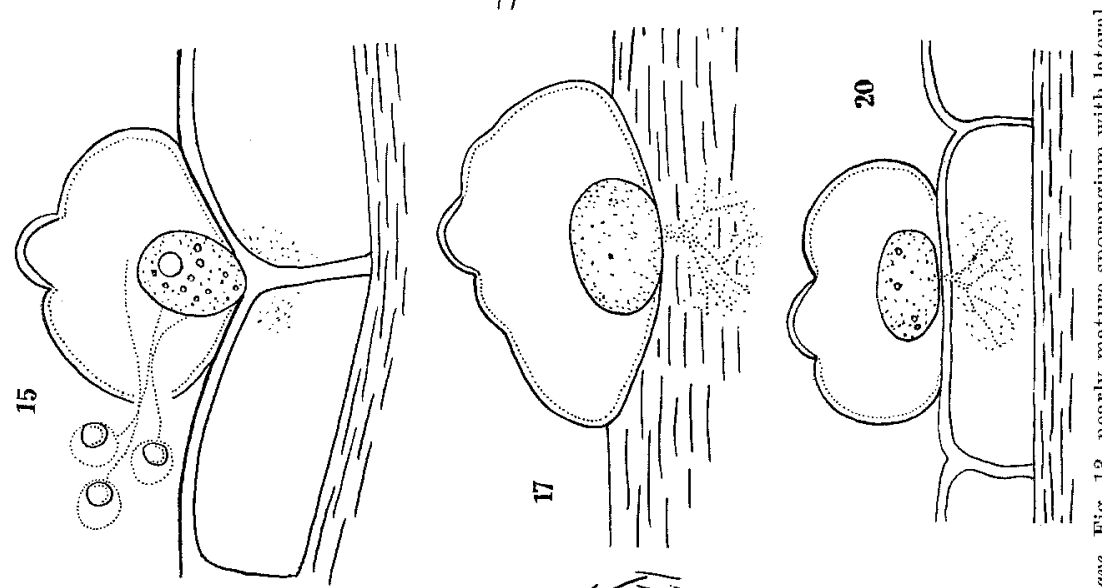

需总

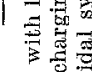

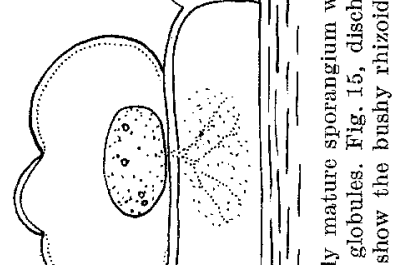

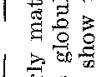

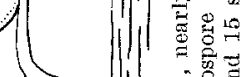

$>$ D

5040
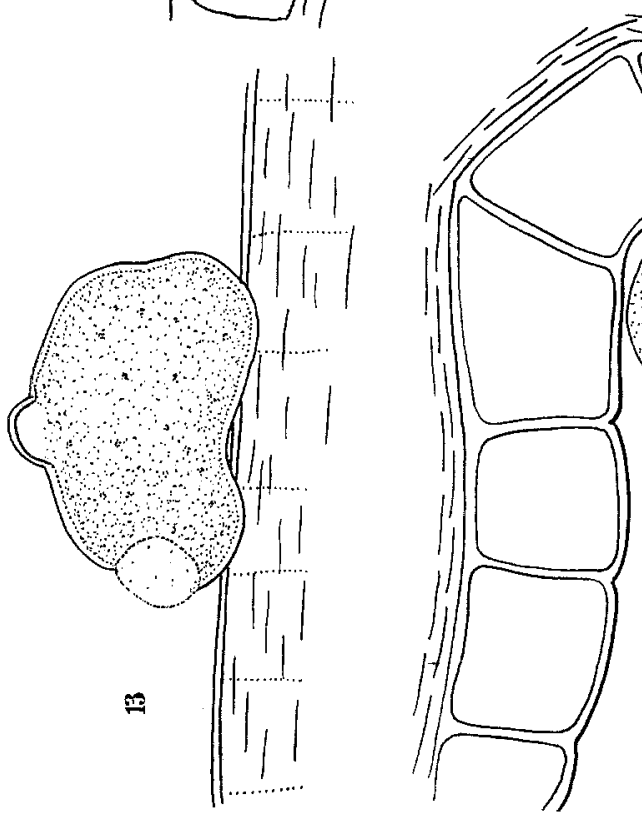

萦它 要这

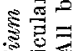
के 岁兽 ge 吅

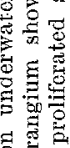
5 焉

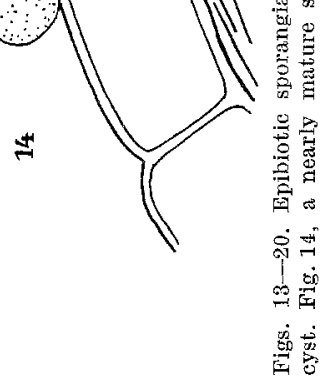


thick-walled structure $8-10 \mu$ in diameter, probably the cyst of the infecting spore. Further development of the endobiotic phase will be described in a later paper.

Just what binomial should be applied to the parasite of Sium must await a thorough study of its host range and of the complex of fungi on different hosts assigned at present to "Physoderma vagans Schroeter".

\section{Physoderma on Potentilla palustris}

At the time of our collections, plants of Potentilla palustris were entirely under water and the palmately compound leaves had not as yet unfolded. Despite their immature condition infected plants already possessed a well developed endobiotic system which bore resting spores, primarily along the mid-rib. Epibiotic sporangia were found in only a few instances and we are not certain that they represent normal material. Again, the opacity of the host tissue made it possible to see only sporangia situated along the margin of the leaf. These were gibbose, transversely placed, $12-15 \mu$ wide by $5-8 \mu$ high, and bore apically the remains of a $3-5 \mu$ in diameter thick-walled cyst. No rhizoidal system could be seen in the dark host cell contents and no zoospores were found. Further observations will be necessary to determine if these are full-sized, typical, sporangia or immature ones, as well as to determine the position of discharge papilla, the nature of the zoospores, and the rhizoidal system.

\section{Physoderma on Sanicula marilandica}

The fungus on Sanicula is probably referable to Physoderma (Urophlyctis) pluriannulatum. Its endobiotic stage has been collected many times from a site in the vicinity of Ann Arbor and will be described in a forthcoming paper, and germination of its resting spores has been followed (SPARRow 1957 a). Very early in June, 1958, plants of Sanicula from a wet ditch recently containing standing water, bore structures on their leaves which were strongly reminiscent of the epibiotic sporangia of Physoderma (Fig.21-27, 29). They were somewhat dome-shaped, $20-30 \mu$ wide by $10-19 \mu$ high with their broad base resting on the outer surface of the host epidermis (i.e. transversely placed). In most instances a thick-walled hemispherical cyst $5 \mu$ wide was seen at the apex. In Fig. 28 is shown a ring of callus associated with the remains of what appears to be the rhizoidal system of the chytrid. The endobiotic rhizoidal system was stubby or finger-like and fairly coarse (Fig. 21, 26, $27,29)$. No zoospore discharge was seen. Occasional specimens bore a discharge pore at one end of the broad base and evidence for internal proliferation of discharged sporangia was also seen (Fig.22). Inasmuch as endobiotic thalli in various early stages of development were found on 

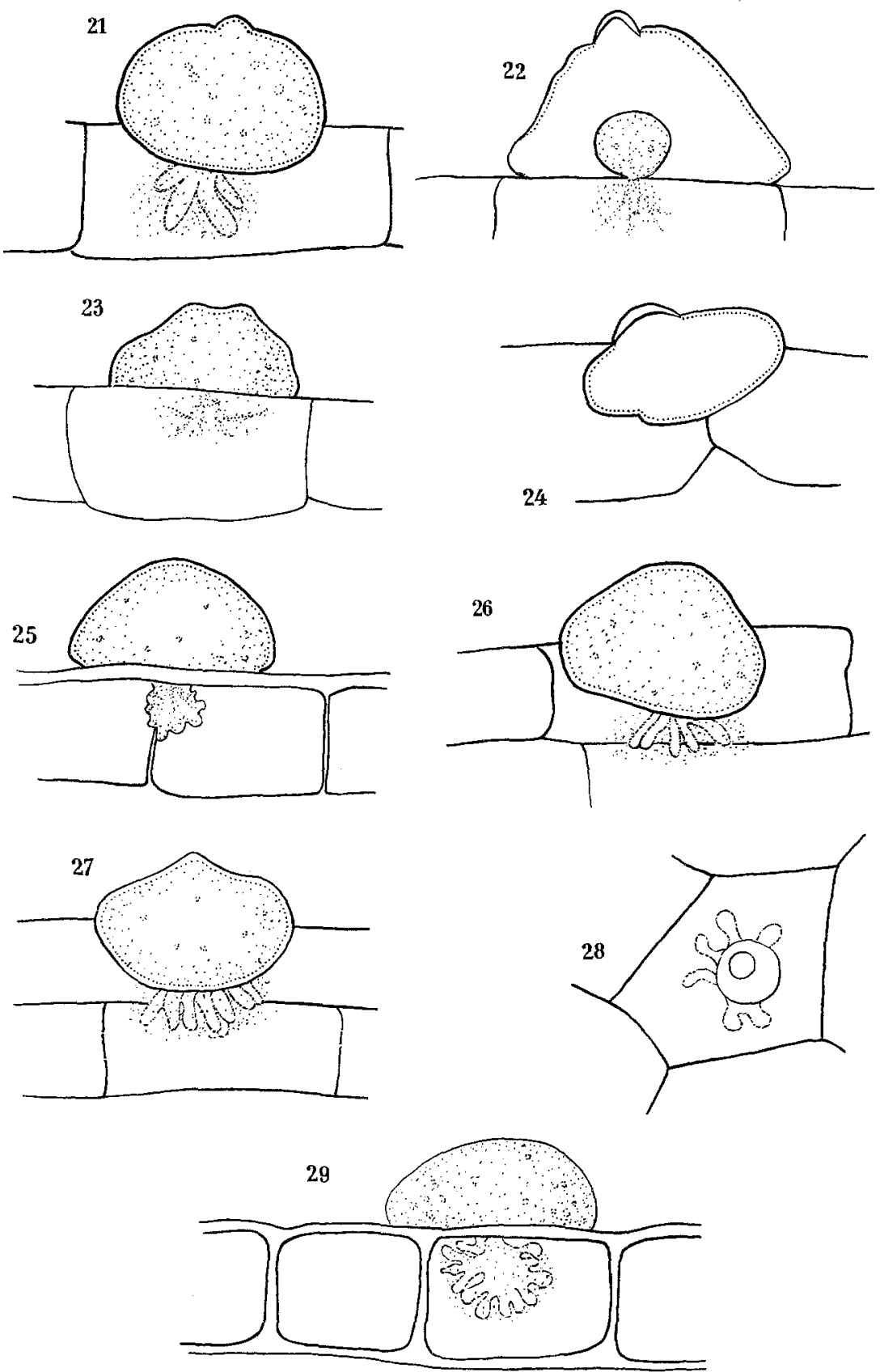

Figs. 21-27, 29. Epibiotic sporangia foumd on plants of Sanicula marilandica infected with Physoderma (Urophlyctis) pluriannulatum. Fig. 28 is a ring of callus-like growth which appears to be the remains of the rhizoidal system of an epibiotic sporangium. x 280 
the same leaves, it was evident that our search for the epibiotic stage should have started sooner. As in the previous fungus, more information is needed before we can say more than that the two stages were associated.

\section{Discussion}

Although field observations alone, cannot, obviously, prove definitely that these thin-walled epibiotic structures belong to the endobiotic stages found later in the season on the same host, we have no hesitancy in believing, at least in the first three fungi described, that they do. The strikingly similar morphological features exhibited, such as the unexpanded portion of the zoospore cyst, bushy rhizoidal system, manner of zoospore discharge, internal proliferation and the occurrence of these epibiotic sporangia on host plants from known Physoderma-infected sites all point to the correctness of this contention.

It is of great interest to know that this stage, which will probably be shown to be a gametangial one in all these species, does actually occur very early in the season in nature and at relatively low temperatures. Furthermore, the strictly aquatic conditions under which the host plants are living at that time provide an ideal environment for the development and dissemination of the epibiotic stage which is entirely comparable to a true aquatic, monocentric chytrid. It is frequently not appreciated that in at least one species of a true Physoderma ( $P$. menyanthis, Sparrow 1940 ) it has been proved that these zoospores may form new epibiotic sporangia. Hence, the number of structures bearing potential gametes, and (as probable) after fusion, the number of zygotes, which initiate the endobiotic stage, is multiplied enormously. Internal proliferation provides still another means of multiplication.

Work is now in progress to produce in the laboratory by means of zoospores from germinated resting spores, epibiotic stages on the hosts mentioned and to compare them with those found in the field.

\section{Literature}

Coucr, J. N.: The occurrence of thin-walled sporangia in Physoderma zeaemaydis on corn in the field. J. Elisha Mitchell Sci. Soc. 69, 182-184 (1953). Johns, R. M.: Thesis, University of Michigan, 1958. - LingaPpa, Y.: Physoderma pulposum. Mycologia (N. Y.) 50, 80-84 (1958). - Sparrow, F. K. : Chytridiaceous fungi in relation to disease in flowering plants, with special reference to Physoderma. In Abstracts of Comm. III. International Congress of Microbiology, New York (1940). - Observations on chytridiaceous parasites of phanerogams. VI. Resting spore germination in Physoderma (Urophlyotis) pluriannulatum. Mycologia (N.Y.) 49, 426-429 (1957a). - Observations on chytridiaceous parasites of phanerogams. VII. A Physoderma on Lycopus americanus. Amer. J. Bot. 44, 661-665 (1957 b). 